\title{
PENGGUNAAN EKSTRAK KASAR BEBERAPA TUMBUHAN DALAM PENGENDALIAN Mycobacterium tuberculosis PENYEBAB PENYAKIT TUBERKULOSIS PADA MANUSIA
}

\section{Use of Crude Extract of Plants to Inhibit Mycobacterium tuberculosis the Cause of Human Tuberculosis Desease}

\author{
Karolina Batvian $^{1}$, Derek Korneles Erari ${ }^{2 *}$, Yenni Yendri Salosa ${ }^{1}$ \\ ${ }^{1}$ Program Studi Biologi, Fakultas Matematika dan Ilmu Pengetahuan Alam Universitas Papua \\ Manokwari, Manokwari 98314, Indonesia \\ ${ }^{2}$ Program Studi Agroteknologi, Fakultas Pertanian, Universitas Papua, Manokwari 98314, Indonesia \\ *Korespondensi: deckyerari17@gmail.com
}

\begin{abstract}
The objective of this reserach is to know the ability of leaf extract of Coleus scutellarioides, Dodonaea viscosa and the seed of Areca catechu as anti-bacterial to inhibit Mycobacterium tuberculosis growth which cause human tuberculosis desease. This research use experimental method with completely rendomized Design (RAL) toward 5 treatments and 4 replications, means 20 treatments in total. Result shows that the crude leaf extracts of C. Scutellarioides and D. viscosa can hamper M. Tuberculosis in 17,25 mm and 10,28 mm inhibition size.
\end{abstract}

\begin{abstract}
ABSTRAK
Penelitian ini bertujuan untuk mengetahui kemampuan ekstrak daun Coleus scutellarioides, Dodonaea viscosa dan ekstrak biji Areca catechu sebagai antibakteri dalam menghambat pertumbuhan M. tuberculosis penyebab penyakit tuberkulosis pada manusia. Metode yang digunakan dalam penelitian ini yaitu metode eksperimen dengan menggunakan Rancangan Acak Lengkap (RAL) terhadap 5 perlakuan dan 4 ulangan sehingga diperoleh 20 percobaan. Hasil penelitian ini menunjukkan bahwa ekstrak kasar daun C. scutellarioides, D. viscosa, terhadap M. tuberculosis dengan besar daya hambat 17,25 mm dan 10,28 mm.
\end{abstract}

Keywords: Plants, Anti-bacterial, Tuberculosis

\section{PENDAHULUAN}

Tuberkulosis (TB) adalah suatu penyakit infeksi yang menular, disebabkan oleh bakteri Mycobacterium tuberculosis. Penyakit ini dapat menyerang semua organ tubuh manusia, terutama paru-paru. Sumber penularan adalah dahak yang mengandung kuman TB. Gejala umum TB paru pada orang dewasa adalah batuk yang terusmenerus dan berdahak selama 3 minggu atau lebih (Sjahrurachman, 2008).

Pengobatan penderitaan TB satu-satunya cara terbaik untuk pengendalian $\mathrm{TB}$ di masyarakat. Hal ini terjadi karena belum tersedianya vaksin yang memberi proteksi tinggi, maka diagnosa akurat diperlukan untuk memulai pengobatan tersebut. Pengobatan yang tidak berdasarkan pada diagnosis yang akurat hanya merugikan semua pihak. Isolasi dan identifikasi dengan cara konvensional merupakan cara untuk mendiagnosa TB. Cara-cara konvensional ini antara lain : uji Tuberkulin, reaksi cepat BCG (Bacillus Calmette Guerin), foto rontgen dada, pemeriksaan mikrobiologi dan serologi, respon terhadap pengobatan dengan Obat Anti Tuberkulosis (OAT) dan lain-lain (Sjahrurachman, 2008).

Jumlah penderita tuberkulosis di Indonesia cukup tinggi. Menurut data World Healthy Organitation, jumlah penderita tuberkulosis di 
Indonesia sekitar 528 ribu atau berada di posisi tiga di dunia setelah India dan Cina (WHO, 2007). Menurut WHO (2010), bahwa pada tahun 2009, peringkat Indonesia menurun ke posisi lima dengan jumlah penderita TBC sebesar 429 ribu orang.

Bakteri Mycobacterium tuberculosis bersifat patogen dan menimbulkan penyakit yang berkisar dari infeksi ringan sampai pada kemaian. Karena itu adanya prosedur untuk mengendalikan pertumbuhan dan kontaminasi oleh bakteri patogen ini merupakan suatu keharusan. Pengendalian mikroorganisme merupakan segala kegiatan yang dilakukan untuk dapat menghambat, membasmi, atau menyingkirkan mikroorganisme baik melalui proses fisik maupun kimia (Pelczar dan Chan, 1998).

Pengobatan tuberkulosis memerlukan waktu yang cukup lama yaitu penggunaan OAT (Obat Anti Tuberkulosis) minimal selama 6 bulan untuk mengobati pasien tuberkulosis dengan pengawasan, sehingga diperlukan biaya yang besar, bahkan dapat menimbulkan efek samping seperti mual, muntah, letih, malas, demam dan gangguan pencemaran. Oleh karena itu diperlukan suatu obat yang lebih murah dan mengurangi resistensi yang dapat menghambat atau membunuh bakteri tuberkulosis, salah satunya melalui penelitian terhadap tanaman obat.

Permasalahan kesehatan yang semakin kompleks memungkinkan tingkat mikroba patogen juga semakin meningkat. Penggunaan antibiotik yang tidak sesuai dengan dosis serta kurangnya pengetahuan dalam bidang kesehatan memicu timbulnya berbagai mikroba patogen menjadi resisten terhadap antibiotik. Kemampuan tumbuhan Coleus scutellarioides, Dodonaea viscosa dan Areca catechu dalam menghasilkan senyawa bioaktif, dapat diarahkan untuk mengendalikan mikroba patogen, salah satunya bakteri tuberkulosis.

Penelitian ini bertujuan untuk mengetahui kemampuan ekstrak kasar daun $C$. scutellarioides, D. viscosa dan biji A. catechu dalam menghambat pertumbuhan bakteri Mycobacterium tuberculosis penyebab penyakit tuberkulosis pada manusia. Manfaat yang diperoleh dengan dilakukan penelitian ini yaitu sebagai informasi tentang potensi ketiga jenis tumbuhan tersebut dalam menghambat pertumbuhan Mycobacterium tuberculosis.

\section{METODE \\ Pengambilan Sampel dan Bakteri Uji}

Sampel daun C. Scutellarioides diperoleh dari Aipiri, daun D. viscosa dihalaman Fakultas Kehutanan, daun yang diambil sebagai sampel adalah daun muda yang telah berbentuk sempurna, yaitu daun nomor 3-5. Biji A. catechu diambil dari halaman Vila Ensly Manunggal Amban Manokwari, buah yang diambil sebagai sampel adalah buah yang telah terbentuk sempurna. Bakteri uji Mycobacterium tuberculosis yang dipesan dari Fakultas Kedokteran UGM Yogyakarta.

\section{Ekstraksi}

Ekstraksi daun dan biji dilakukan di Laboratorium Kimia FMIPA UNIPA. Ekstraksi daun C. Scutellarioides, D. viscosa, biji A. catechu dilakukan dengan metode Peredaman (Maserasi) menurut Dadang dan Nugroho (1999): a. Sampel daun C. Scutellarioides, D. viscosa, dan potongan tipis biji A. catechu diambil dan dikeringkan pada suhu ruangan.

b. Setiap sampel yang telah kering diambil dan di blender hingga membentuk serbuk.

c. Serbuk diambil dan ditimbang sebanyak $50 \mathrm{gr}$ kemudian direndam dengan metanol 96\% selama 3x24 jam, dengan perbandingan 1:5 (sampel $50 \mathrm{gr}$ : metanol $250 \mathrm{ml}$ ).

d. Hasil maserasi atau peredaman tersebut disaring dengan menggunakan kertas saring Whatman No 41, filtrat diperoleh melalui penyaringan, dan dievaporasi menggunakan Vaccum Rotary Evaporator pada suhu $68^{\circ} \mathrm{C}$ di Laboratorium Kimia Fakultas MIPA UNIPA.

e. Selanjutnya ekstrak daun C. Scutellarioides, D. viscosa, dan biji A. catechu disimpan dalam lemari es sampai saat digunakan untuk uji bakteri.

f. Hasil evaporasi dari ekstrak kasar daun C. Scutellarioides, D. viscosa, biji A. catechu dalam bentuk pasta dengan konsentrasi $100 \%$.

\section{Pembuatan Media}

Pembuatan media, sterilisasi alat dan bahan dilakukan di Laboratorium Mikrobiologi FMIPA UNIPA. Media Nutrient Broth (NB) 
dan media Nutrient Agar (NA) dibuat menurut Cappuccino dan Natalie (2001). Sterilisasi alat dan bahan pada suhu $121{ }^{\circ} \mathrm{C}$ autoclave dengan tekanan $1 \mathrm{~atm}$ selama 15-30 menit.

\section{Pembuatan Suspensi Bakteri Uji}

Isolat bakteri diambil sebanyak satu ose dan diinokulasi pada media NB. Setelah itu isolat bakteri diinkubasi selama 1x24 jam (Cappuccino dan Natalie, 2001).

\section{Pengujian Kemampuan Daya Hambat Mycobacterium tuberculosis}

Pengujian kemampuan daya hambat Mycobacterium tuberculosis dilakukan menurut metode Agar Cakram Kertas yang dikemukakan oleh Kasim et al., (2005). Pengujian yang sama dilakukan juga terhadap kontrol negatif (air) dan kontrol positif antibiotika (Isoniazid). Metode agar cakram kertas merupakan salah satu metode yang paling sering digunakan dalam penelitian mikrobiologi untuk pengujian antibakteri, Agar cakram kertas dapat menunjukkan kemampuan zat antibakteri dalam menghambat atau mematikan pertumbuhan bakteri. Pengamatan dilakukan terhadap zona hambat disekeliling paper disk yang menunjukkan daerah hambatan pertumbuhan bakteri. Zona hambat yang terbentuk diukur dari batas terluar paper disk sampai batas luar zona hambat. Pengukuran dilakukan dengan menggunakan kaliper.

Pengujian penghambatan ekstrak daun $\mathrm{C}$. Scutellarioides, D. viscosa, biji A. catechu terhadap bakteri uji Mycobacterium tuberculosis:

a. Media NA yang telah disterilkan dan masih dalam keadaan cair di tuang ke dalam cawan petri masing 2 sebanyak $20 \mathrm{ml}$.

b. Sebanyak $0,1 \mathrm{ml}$ bakteri dari media NB diteteskan pada media NA dalam cawan petri lalu diratakan dengan sprider menggunakan Metode sebar.

c. Kemudian selanjutnya paper disk dicelupkan pada ekstrak yang akan diuji, yaitu daun C. Scutellarioides, D. viscosa, biji A. catechu selama 1 menit, lalu paper disk hasil celupan diletakkan pada permukaan media NA.

d. Setelah itu media ditutup dengan plastik warp masukan dalam plastik gula dan diinkubasi selama 24-48 jam pada suhu ruangan. e. Zona hambat terbentuk diukur dari batas terluar paper disk sampai batas luar zona hambat. Pengukuran zona hambat dilakukan dengan menggunakan kaliper.

Uji penghambatan kontrol negatif (air steril) dan kontrol positif INH (Isoniazid) dengan konsentrasi $300 \mathrm{mg}$ dalam $10 \mathrm{ml}$ aquades prosedur pengerjaannya sama dengan cara di atas.

\section{Variabel Pengamatan}

Variabel yang diamati pada penelitian ini adalah diameter zona hambat berupa daerah bening pada permukaan medium antara ekstrak C. Scutellarioides, D. viscosa, biji A. catechu dengan Mycobacterium tuberculosis dan membandingkan besarnya diameter yang terbentuk. Metode pengukuran zona hambat dapat dilihat pada Gambar 1.

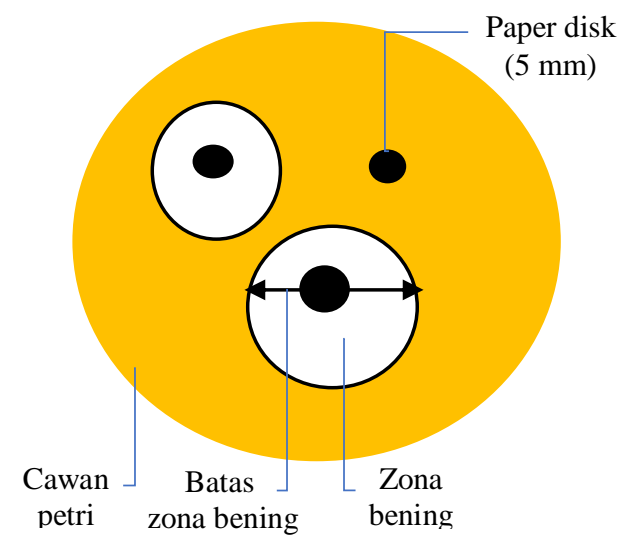

Gambar 1. Letak paper disk dan cara pengukuran zona hambat

\section{Analisis Data}

Data analisis hasil pengamatan diperoleh dalam bentuk kualitatif dan kuantitatif. Nilai pengamatan kualitatif disajikan dalam bentuk gambar, sedangkan untuk nilai kuantitatif dilakukan dengan perhitungan rata-rata sesuai dengan pola rancangan yang digunakan, lalu disajikan dalam bentuk Tabel 1 (Halsm, 2003).

Tabel 1. Kekuatan daerah hambatan untuk zat Antibakteri

\begin{tabular}{lll}
\hline No & $\begin{array}{c}\text { Daerah } \\
\text { Hambatan }(\mathrm{mm})\end{array}$ & $\begin{array}{c}\text { Respon Hambatan } \\
\text { Pertumbuhan }\end{array}$ \\
\hline 1 & $\geq 20$ & Sangat Kuat \\
2 & $10-20$ & Kuat \\
3 & $5-10$ & Sedang \\
4 & $\leq 5$ & Lemah \\
\hline
\end{tabular}




\section{HASIL DAN PEMBAHASAN}

\section{Ekstrak Daun dan Biji}

Daun Miana (C. scutellarioides) dan daun Sikil (D. viscosa) dalam kondisi baik dan tidak terkena penyakit, sedangkan biji pinang (A. catechu) dalam kondisi sempurna dan masih utuh. Sampel daun dan biji ini terkandung senyawa metabolit sekunder. Daun muda umumnya telah menghasilkan senyawa metabolit sekunder walaupun jumlahnya tidak sebanyak daun tua (Nuringtyas et al., 2007). Senyawasenyawa metabolit biasanya digunakan untuk proteksi diri.

Proses pengeringan C. scutellarioides, D. viscosa, A. catechu dengan cara dikeringanginkan selama 10 hari telah menghindarkan kerusakan kandungan kimia dari daun akibat pemanasan berlebihan. Daun diblender hingga menjadi serbuk, kemudian serbuk ditimbang sebanyak 50 gr dan direndam dengan metanol $96 \%$.
Metanol dinilai baik karena sifatnya yang hampir dapat melarutkan semua senyawa organik yang terdapat didalam tumbuhan baik yang bersifa polar maupun non polar, titik didihnya tidak terlalu tinggi $\left(68^{\circ} \mathrm{C}\right)$ sehingga mudah diuapkan (Nassel, 2008). Pada proses perendaman, komposisi metanol lebih banyak daripada serbuk daun dan biji dengan tujuan agar berbagai bahan aktif yang terdapat didalam selsel tumbuhan dapat terikat. Proses ini menguntungkan karena dengan perendaman daun C. scutellarioides, D. viscosa, dan biji A. catechu, mengakibatkan pemecahan dinding sel dan membran sel akibat perbedaan tekanan antara didalam sel dan diluar sel sehingga senyawa metabolit sekunder yang ada dalam sitoplasma terlarut dalam pelarut. Daun C. scutellarioides, D. viscosa, dan biji A. catechu yang diblender menjadi serbuk kasar dan produk perendaman ditunjukkan dalam Gambar 2.
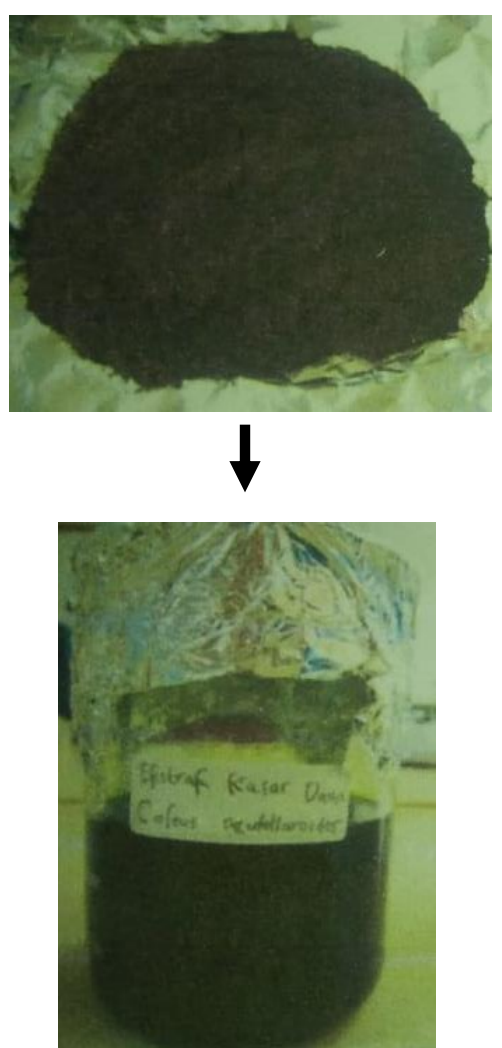

A
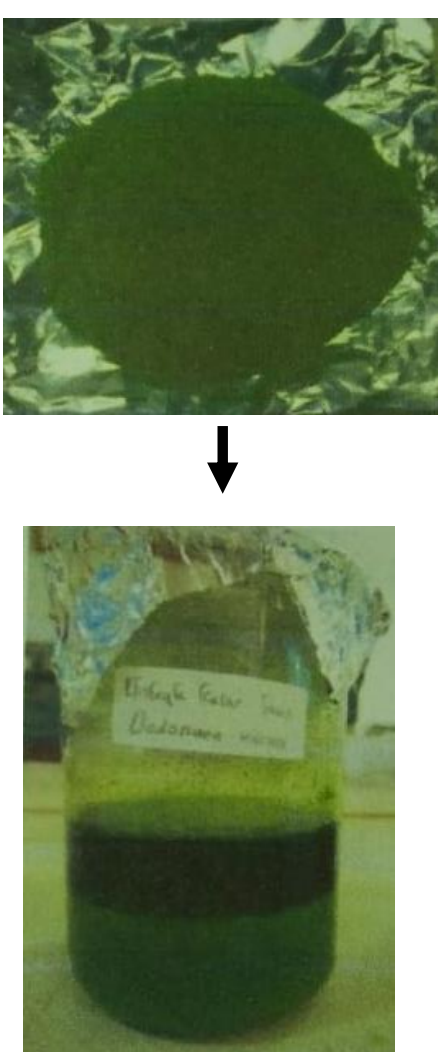

$\mathrm{B}$
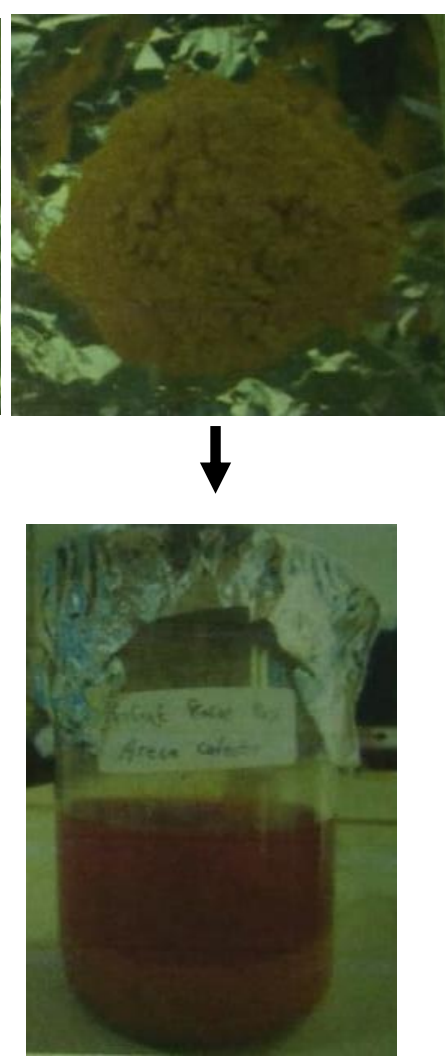

$\mathrm{C}$

Gambar 2. Daun C. scutellarioides (A), D. viscosa (B), dan biji A. catechu (C) yang diblender menjadi serbuk kasar (atas) dan hasil proses maserasi (bawah). Maserasi (perendaman) dilakukan selama 3x24 jam untuk memaksimalkan bahan aktif yang dapat diserap oleh pelarut. 


\section{Uji Daya Hambat Bakteri}

Hasil ekstrak daun C. scutellarioides, D. viscosa, dan biji A. catechu selanjutnya diujikan pada pertumbuhan bakteri Mycobacterium tuberculosis. Berdasarkan uji tersebut ternyata ekstrak kasar C. scutellarioides, D. viscosa dapat menghambat pertumbuhan Mycobacterium tuberculosis. Penghambatan ditunjukkan oleh adanya zona hambat yang terbentuk disekeliling paper disk (Gambar 3).

Zona hambat yang terbentuk oleh penghambatan ekstrak daun C. scutellarioides, D. viscosa terhadap bekteri Mycobacterium tuberculosis dalam waktu $2 \times 24$ jam tampak jelas. Setelah melewati waktu tersebut mulai tampak ada koloni bakteri yang mulai tumbuh disekitar zona hambat. Ini menunjukkan ekstrak daun C. scutellarioides, D. viscosa dan INH (Isoniazid) tergolong bakteriostatik, yaitu zat antibakteri yang memiliki aktivitas menghambat pertumbuhan bakteri dimana mampu menghambat perbanyakan populasi bakteri, namun tidak mematikan (Irianto, 2006).

Zona hambat yang terbentuk disekeliling paper disk kemudian diukur menggunakan kaliper. Hasil pengukuran diameter zona hambat merupakan gabungan dari daerah bening dan paper disk yang diameternya $5 \mathrm{~mm}$ (Tabel 2). Diameter zona hambat yang tertinggi terjadi pada
M (Daun C. scutellarioides), sedangkan K (-) atau kontrol negatif dan P (biji A. catechu) tidak dapat menghambat pertumbuhan bakteri.

Berdasarkan uji analisis sidik ragam (ANOVA) menunjukkan bahwa pemberian INH (Isoniazid), ekstrak daun C. scutellarioides, dan daun D. viscosa berpengaruh sangat nyata dalam penghambatan pertumbuhan Mycobacterium tuberculosis dimana Fhitung $(36,5442)>$ Ftabel $(4,89)$. Kemudian dilanjutkan dengan Uji Beda Nyata Jujur (BNJ), angka yang diikuti huruf yang sama tidak adanya perbedaan yang nyata dengan Uji Beda Nyata Jujur (BNJ) pada taraf kepercayaan $99 \%$.

Hasil analisis menunjukkan bahwa semua perlakuan memiliki hasil yang berbeda, kecuali perlakuan K (-) dan P menunjukkan kesamaan. Tidak adanya perbedaan, ini menunjukkan bahwa pinang tidak memiliki kemampuan dalam menghambat pertumbuhan Mycobacterium tuberculosis. Bila dibandingkan dengan perlakuan dari ekstrak lainnya yaitu, C. scutellarioides, D. viscosa, K (+), berbeda satu sama lain dan mempunyai kemampuan dalam menghambat Mycobacterium tuberculosis. Tingkat penghambatan pertumbuhan bakteri ini dapat digolongkan berdasarkan kemampuan penghambatan bakteri oleh Halsm (2003) pada Tabel 3.

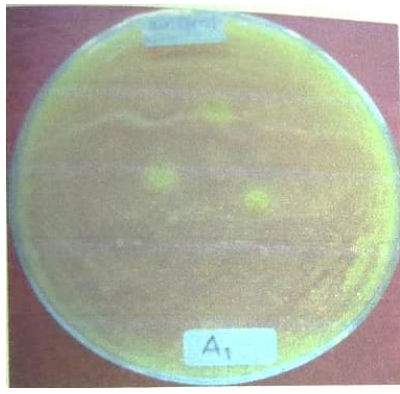

A

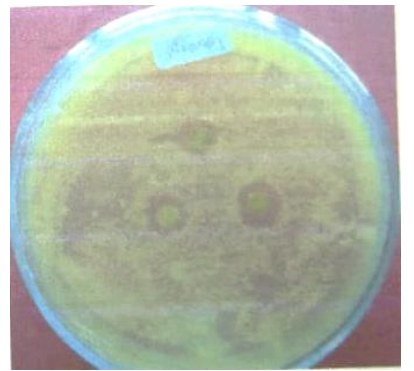

D

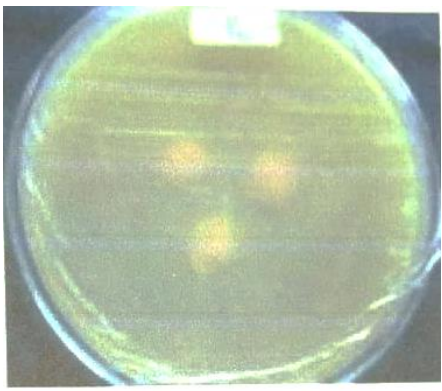

B

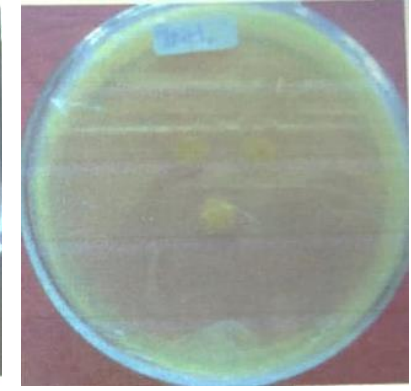

$\mathrm{C}$

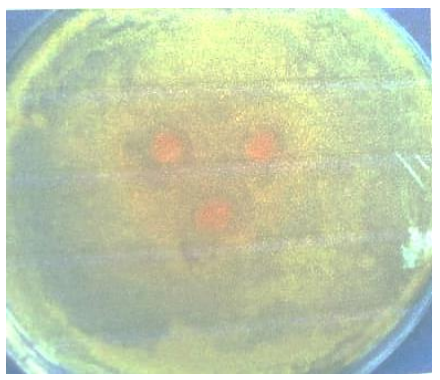

$\mathrm{E}$

Gambar 3. Zona hambat yang terbentuk oleh penghambat. K (-) air steril (A); ekstrak biji A. catechu (B); INH Isoniazid (C); ekstrak daun C. scutellarioides (D); ekstrak daun D. viscosa (E). 
Tabel 2. Hasil Pengukuran zona hambat (mm) ekstrak kasar daun C. scutellarioides, D. viscosa, biji A. catechu terhadap pertumbuhan Mycobacterium tuberculosis. K (-)= kontrol negatif (air steril); $\mathrm{P}=$ biji A. catechu; $\mathrm{K}(+)=$ kontrol positif INH (isoniazid); $\mathrm{D}=$ daun D. viscosa; $\mathrm{M}=$ daun $\mathrm{C}$. scutellarioides; ${ }^{*}=$ sangat nyata.

\begin{tabular}{|c|c|c|c|c|c|c|}
\hline \multirow{2}{*}{ Perlakuan } & \multicolumn{4}{|c|}{ Ulangan } & \multirow{2}{*}{ Jumlah } & \multirow{2}{*}{$\begin{array}{c}\text { Nilai Rata-rata } \\
\text { Diameter }(*)\end{array}$} \\
\hline & I & II & III & IV & & \\
\hline K (-) & 0 & 0 & 0 & 0 & 0 & $0 \mathrm{a}$ \\
\hline $\mathrm{P}$ & 0 & 0 & 0 & 0 & 0 & $0 \mathrm{a}$ \\
\hline $\mathrm{K}(+)$ & 10.6 & 11 & 10 & 3.3 & 34.9 & $8.73 b$ \\
\hline $\mathrm{D}$ & 10.3 & 11.3 & 9.5 & 10 & 41.1 & $10.28 \mathrm{c}$ \\
\hline M & 12.4 & 15.6 & 20.5 & 20.5 & 69 & $17.25 \mathrm{~d}$ \\
\hline Total & 33.3 & 37.9 & 40 & 33.8 & 145 & 36.26 \\
\hline
\end{tabular}

Tabel 3. Penggolongan Kekuatan Daya Hambat Ekstrak Kasar daun C. scutellarioides, D. viscosa, biji A. catechu terhadap pertumbuhan Mycobacterium tuberculosis. $\mathrm{K}(-)=$ kontrol negatif (air steril); $\mathrm{M}=$ daun C. scutellarioides; $\mathrm{D}=$ daun $\mathrm{D}$. viscosa; $\mathrm{P}=$ biji A. catechu; $\mathrm{K}(+)=$ kontrol positif INH (isoniazid).

\begin{tabular}{cccccc}
\hline Perlakuan & $\begin{array}{c}\text { Diameter } \\
\text { zona hambat } \\
(\mathrm{mm})\end{array}$ & \multicolumn{4}{c}{ Penggolongan respon hambatan berdasarkan Halsm (2003) } \\
\cline { 3 - 6 } & 0 & $\begin{array}{c}\leq 5 \\
(\text { Lemah })\end{array}$ & $\begin{array}{c}5-10 \\
(\text { Sedang })\end{array}$ & $\begin{array}{c}10-20 \\
(\text { Kuat })\end{array}$ & $\begin{array}{c}\geq 20 \\
\text { (Sangat Kuat) }\end{array}$ \\
\hline $\mathrm{K}(-)$ & 17.25 & $\sqrt{ }$ & $\sqrt{ }$ & \\
$\mathrm{M}$ & 10.28 & & & $\sqrt{ }$ \\
$\mathrm{D}$ & 0 & $\sqrt{ }$ & & \\
$\mathrm{P}$ & 8.73 & & $\sqrt{ }$ & \\
$\mathrm{K}(+)$ & & &
\end{tabular}

Berdasarkan penggolongan Tabel 3, karena daun C. scutellarioides mengandung respon penghambatan ekstrak kasar daun C. senyawa-senyawa kimia seperti minyak atsiri, scutellarioides, daun D. viscosa dan biji A. fenol, tanin, lemak, fitosterol (Winarto, 2007). catechu terhadap bakteri Mycobacterium Berdasarkan penelitian pendahuluan yang tuberculosis masing-masing tersebar dari lemah, dilakukan Suwarji (1987) daun C. scutellarioides sedang hingga kuat. Perlakuan K (-) atau kontrol juga mengandung senyawa alkaloid, flavanoid negatif dan P (Biji A. catechu) tidak ada daya dan saponin. Penelitian yang dilakukan Wagey hambat yang terbentuk, sedangkan pada (2010) ekstrak kasar daun C. scutellarioides perlakuan $\mathrm{K}(+)$ atau krol positif INH (Isoniazid) mampu menghambat bakteri E. coli dan S. termasuk dalam kategori sedang, dimana ada daya hambat yang terbentuk yaitu $8.73 \mathrm{~mm}$. Konsentrasi dengan kategori kuat adalah M (daun C. scutellarioides) dan D (daun D. viscosa) dengan diameter $17.25 \mathrm{~mm}$ dan $10.28 \mathrm{~mm}$.

Daun C. scutellarioides, dan D. viscosa merupakan tanaman yang dikenal sebagai tanaman obat. Kemampuan ekstrak kasar daun C. scutellarioides dan D. viscosa dalam menghambat Mycobacterium tuberculosis diduga aureus.

Daun D. viscosa mengandung senyawa lakaloid, flavonoid, fenol hidrokarbon, steroid, triterpenoid, tanin dan saponin. Berdasarkan penelitian yang dilakukan Maturbongs (2011) mengatakan bahwa daun D. viscosa kaya akan kandungan flavonoid. Ekstrak kasar daun D. viscosa mengandung senyawa metabolit sekunder yang dapat menghambat bakteri E. coli dan S. aureus. Senyawa inilah yang diduga telah 
berperan aktif dalam menghambat pertumbuhan Mycobacterium tuberculosis. Menurut Cahyadi (2008) senyawa bioaktif merupakan senyawa metabolik sekunder yang bersifat aktif secara biologis, aktivitasnya yaitu sebagai antimikroba.

Pertumbuhan bakteri yang terhambat atau kematian suatu bakteri akibat suatu zat antibakteri dapat disebabkan oleh penghambatan terhadap sintesis dinding sel, fungsi membran sel, sintesis protein atau penghambatan sintesis asam nukleat. Senyawa alkaloid dapat mengganggu terbentuknya jembatan silang komponen penyusun peptidoglikan pada sel bakteri, sehingga lapisan dinding sel tidak terbentuk secara utuh dan menyebabkan kematian sel (Robinson, 1995). Senyawa alkaloid mengandung gugus nitrogen dan biasanya terkonsentrasi pada jumlah yang tinggi pada bagian tanaman tertentu. Sebagai contoh pada salah bagian tanaman tidak mengandung alkaloid tetapi bagian tanaman yang lain sangat kaya akan alkaloid. Senyawa ini biasa terdapat pada biji, buah, daun, akar dan pada kulit batang (Nadjeeb, 2009). Salah satu fungsi alkaloid adalah sebagai racun untuk melindungi tanaman dari serangga dan hewan, tetapi ada pula yang sangat berguna dalam pengobatan misalnya kuinin, morfin dan stiknin. Alkaloid termasuk dalam senyawa yang bersifat basa (Lenny, 2006).

Sebagian besar senyawa flavonoid alam ditemukan dalam bentuk glikosida, dimana unit flavonoid terikat pada suatu gula. Glikosida adalah kombinasi antara suatu gula dan suatu alkohol yang saling berikatan melalui ikatan glikosida (Lenny, 2006). Menurut Robinson (1995), kegunaan flavonoid antara lain sebagai pengatur tubuh, pengatur fotosintesis, kerja antimikroba dan antivirus. Menurut Volk dan Wheller (1993), flavonoid merupakan salah satu antibakteri yang bekerja dengan mengganggu fungsi membran sitoplasma.

Polifenol juga merupakan senyawa metabolit sekunder tanaman, didalam daun Sikil (D. viscosa) yang tergolong polifenol adalah fenol hidrokarbon dan tanin. Menurut Robinson (1995), polifenol berperan membantu proses fisiologi tumbuhan, beberapa senyawa fenolik bersifat racun terhadap hewan pemangsa (herbivora), sebagai insektisida dan pada tumbuhan tertentu senyawa ini dibentuk sebagai tanggapan terhadap infeksi oleh jamur. Secara khusus tanin dikatakan berfungsi sebagai pertanhanan bagi tumbuhan, menurunkan nilai gizi tumbuhan makanan ternak dan mempunyai aktivitas antioksidan.

Menurut Hartono (2009), saponin merupakan racun yang dapat menghancurkan butir darah atau hemolisis pada darah. Saponin bersifat racun bagi hewan berdarah dingin dan banyak diantaranya digunakan sebagai racun ikan. Saponin bersifat keras disebut sebagai sapotoksin. Saponin diklasifikasikan menjadi dua yaitu: saponin steroid dan saponin triterpenoid. Saponin steroid tersusun atas inti steroid dengan molekul karbohidrat. Saponin steroid dihidrolisis menghasilkan suatu aglikon yang dikenal sebagai saraponin. Tipe saponin ini memiliki antifungi. Saponin steroid dieksresikan setelah konjugasi dengan asam glukoronida dan digunakan sebagai bahan baku pada proses biosintesis dari obat kortikosteroid. Saponin triterpenoid tersusun atas inti triterpenoid dengan molekul karbohidrat. Dihidrolisis menghasilkan suatu aglikon yang disebut sapogenin (Hartono, 2009).

Berdasarkan pemanfaatan secara tradisional daun C. scutellarioides dan daun D. viscosa digunakan sebagai obat diare yang disebabkan oleh bakteri Escherichia coli dan berdasarkan aktivitas fisiologis dari senyawa golongan triterpenoid bebas dapat berfungsi sebagai antibakteri. Menurut Rumbiak (2010) C. scutellarioides dimanfaatkan oleh suku Hattam sebagai obat penyembuh sakit kepala, luka, flu dan batuk serta dijadikan tanaman hias.

Berdasarkan uraian diatas, diketahui obat tradisional daun C. scutellarioides dan D. viscosa mengandung berbagai senyawa yang berpotensi dalam menghambat pertumbuhan bakteri patogen Mycobacterium tuberculosis. Zona hambat yang terbentuk merupakan hasil kerja dari gabungan senyawa-senyawa kimia tersebut. Belum dapat diketahui senyawa apa yang paling berperan dalam penghambatan pertumbuhan bakteri secara khusus bakteri Mycobacterium tuberculosis.

Isoniazid (INH) secara invitro bersifat tuberkulostatik menahan perkembangan bakteri dan tuberkulosid membunuh bakteri (Agrawati, 2010). Penghambatan pertumbuhan Mycobacterium tuberculosis pada penelitian ini menunjukkan bahwa isoniazid dapat menahan 
perkembangan bakteri tuberkulosis yang ditunjukkan dengan adanya zona hambat disekitar paper disk dan zona hambat yang terbentuk yaitu $8,73 \mathrm{~mm}$ atau dalam kategori sedang. Isoniazid merupakan hidrazid asam isonikotinat, senyawa ini didapat dari kristalisasi alkohol. Isoniazid (INH) memiliki efek pada lemak, biosintesis asam nukleat dan glikolisis. Efek utamanya adalah menghambat biosintesis asam mikolat (mycolic acid) yang merupakan unsur penting dinding dinding sel mikobakterium. Isoniazid menghilangkan sifat tahan asam dan menurunkan jumlah lemak yang terekstraksi oleh metanol dari mikobakterium (Agrawati, 2010).

Biji A. catechu secara umum telah dikenal masyarakat sebagai bahan obat tradisional. Biji A. catechu seperti halnya antibiotika mempunyai daya hambat antibakteri. Kemampuan ekstrak biji A. catechu dalam menghambat bakteri Staphylococcus aureus. Diduga karena adanya senyawa kimia seperti tanin, alkaloid, arekoline dan guvakolin didalam ekstrak biji A. catechu (Heyne, 1987). Senyawa-senyawa itulah yang berperan sebagai bahan aktif yang dapat menghambat pertumbuhan bakteri S. aureus, serta merupakan senyawa metabolit sekunder tumbuhan yang aktif dalam menghambat pertumbuhan bakteri.

Menurut Sumarni (2010) ekstrak biji A. catechu dapat menghambat pertumbuhan bakteri patogen S. Aureus. Namun dalam penelitian ini ekstrak biji A. catechu tidak berpengaruh dalam menghambat pertumbuhan M. tuberculosis. Diduga karena adanya perbedaan sifat dari kedua bakteri patogen tersebut, dan juga penggunaan pelarut dalam proses maserasi (perendaman).

Mycobacterium tuberculosis cenderung lebih resisten terhadap faktor kimia dari pada bakteri yang lain karena sifat hidrofobik permukaan selnya dan pertumbuhan bergerombol (Mutchler, 1991). M. tuberculosis tidak menghasilkan kapsul atau spora serta dinding selnya terdiri dari peptidoglikan dengan kandungan lipid kira-kira setinggi 60\%, pada dinding sel Mycobacteria, lemak berhubungan dengan arabinogalaktan dan peptidoglikan dibawahnya, struktur ini menurunkan permeabilitas dinding sel, sehingga mengurangi aktifitas dari antibiotik. Bakteri Staphylococcus aureus merupakan penyebab penyakit infeksi, dalam keadaan normal, terapat pada saluran pernafasan atas, kulit, saluran cerna dan vagina (Enjtjang, 2003). Staphylococcus dapat menginfeksi setiap jaringan tubuh ataupun alat tubuh dan dapat menyebabkan timbulnya penyakit dengan tanda-tanda yang khas yaitu peradangan dan pembentukkan abses. Staphylococcus aureus merupakan bakteri yang berbentuk bola, dengan diameter $1 \mu \mathrm{m}$ yang tersusun dalam bentuk kluster yang tidak teratur. Kokus tunggal, berpasangan, tetrat dan berbentuk rantai juga tampak dalam biakan cair. Bakteri ini merupakan bakteri yang tidak memiliki spora, tidak bergerak dan dapat tumbuh diberbagai media pada suasana aerob (Enjtjang, 2003).

\section{SIMPULAN}

Ekstrak kasar daun Miana (C. scutellarioides), daun Sikil (D. viscosa) dapat menghambat pertumbuhan Mycobacterium tuberculosis dengan luas hambatan $17.25 \mathrm{~mm}$ dan $10.28 \mathrm{~mm}$ tergolong kuat karena mengandung berbagai senyawa kimia yang berperan dalam proses penghambatan pertumbuhan bakteri. Ternyata ekstrak kasar biji Pinang (A. catechu) tidak dapat menghambat pertumbuhan Mycobacterium tuberculosis. Fenomena ini mungkin terjadi karena dua penyebab: 1) pelarut metanol yang digunakan tidak efektif dalam mengeluarkan zat metabolit sekunder yang terkandung dalam biji Pinang, dan 2) perbedaan sifat bakteri uji yang digunakan.

\section{DAFTAR PUSTAKA}

Agrawati S. 2010. Tuberkulostatik, Obat dan Efek Sampingnya. Karya tulis Ilmiah Sarjana Kedokteran Bagian Parasitologi. Sumber IONI. Jakarta.

Cahyadi W. 2008. Analisis Aspek Kesehatan Bahan Tambahan Pangan, Edisi Kedua. Bumi Aksara. Jakarta.

Cappuccino JG, Natalie S. 2001. Microbiology A Laboratory Manual. State University Of New York.

Dadang, Nugroho BW. 1999. Ekstraksi, Isolasi, dan Identifikasi. Bahan Pelatihan Pengembangan dan Pemanfaatan Insektisida Alami. Pusat Kajian PHT. 
Enjtjang. 2003. Mikrobiologi dan Parasitologi. PT Citra Aditya Bakti. Bandung.

Hartono T. 2009. Saponin. http://farmasi.dikti. net/saponin/

Halms. 2003. Biokimia dan Toksikologi. FMIPA IPB. http://www.beritaiptek. com

Heyne K. 1987. Tumbuhan Berguna Indonesia. Jilid 1. Yayasan Sarana Wana Jaya. Hal: 460-465

Irianto K. 2006. Mikrobiologi: Menguak Dunia Mikroorganisme. Yrama Widya. Bandung.

Kasim E, Khan MA, Hameed AN, Qayam A, Inayat H. 2009. Antibacerial Activities of Dodonaea viscosa Using Contact Bioautography Technique. J. Molecules, 14, doi:10.3390/molecules, Hal. 13321341.

Lenny S. 2006. Senyawa Flavonoida, Fenilpropanoida dan Alkaloida. Makalah Mahasiswa Jurusan Kimia Fakultas Matematika dan Ilmu Pengetahuan Alam Universitas Sumatera Utara. Sumatera Utara.

Maturbongs A. 2011. Daya Hambat Ekstrak Daun Dodonaea viscosa (L) Jacq terhadap Pertumbuhan Escherechia coli ATCC 25922 dan Staphylococcus aureus ATCC 25923. Skripsi Program Studi Biologi Fakultas Matematika dan Ilmu Pengetahuan Alam. Manokwari. (tidak diterbitkan).

Mutclher. 1991. Virology and Bacteriology. WB Saunders Company. Philadelphia.

Nadjeeb. 2009. Alkaloid. http://nadjeeb.files. wordpress.com/2009/03/alkaloid.pdf

Nassel FM. 2008. Isolasi Alkaloid Utama dari

Tumbuhan Lerchea interrupta Korth. Percikan, 91:57-66.

Nuringtyas TR, Purwanto H, Rochayati A. 2007. Senyawa Metabolit Sekunder Pada Daun Muda dan Tua Empat Jenis Tanaman Pakan Alami Ulat Atakas (Attacus atlas L). Biologi, 6 (1):63-70.

Pelczar MJ, Chan ECS. 1998. Dasar-Dasar Mikrobiologi I. UI-Press. Jakarta.
Robinson T. 1995. Kandungan Organik Tumbuhan Tinggi. ITB. Bandung.

Rumbiak O. 2010. Variasi Coleus spp dan Pemanfaatannya oleh Suku Hattam di Kampung Gueintuy Distrik Warmare Kabupaten Manokwari. Skripsi Program Studi Ilmu Pengetahuan Alam. Manokwari (tidak diterbitkan).

Sjahrurachman A. 2008. Kultur dan Uji Kepekaan Mycobacterium tuberculosis Terhadap Obat Anti Tuberkulosis Lini Pertama. Departemen Kesehatan RI.

Sumarni. 2010. Daya Hambat Ekstrak Biji Pinang (Areca catechu) terhadap Staphylococcus aureus. Skripsi Program Studi Biologi Fakultas Matematika dan Ilmu Pengetahuan Alam. Manokwari. (tidak diterbitkan).

Suwarji H. 1987. Pemeriksaan Pendahuluan Kandungan Kimia Daun Her (Coleus atropurpureus Benth). Jurusan Farmasi UNPAD.

Volk, Wheeler. 1993. Mikrobiologi Dasar Jilid I Edisi Kelima. Alih Bahasa: Markham. Erlangga. Jakarta.

Wagey F. 2010. Daya Hambat Ekstrak Kasar Daun Miana (Coleus scutellarioides (L.) Benth) Terhadap Staphylococcus aureus dan Escherica coli. Skripsi Program Studi Biologi Fakultas Matematika dan Ilmu Pengetahuan Alam. Manokwari. (tidak diterbitkan).

Winarto WP. 2007. Tanaman Obat Indonesia untuk Pengobatan Herba Jilid I. Karyasari Herba Media. Jakarta.

WHO. 2007. Penderita TB Indonesia terbanyak ketiga Dunia. http://www.antarnews.com/ view/?i= $1248166539 \mathrm{c}=\mathrm{NASs}=\mathrm{KES}$

WHO. 2010. Jumlah Penderita Tuberkulosis di Indonesi menduduki posisi kelima terbesar di Dunia. http://mediasinar timur.com/ whojumlah-penderita-tuberculosis-diindonesia-menduduki-posisi-kelimaterbesar-di-dunia.html 